\title{
大学生の環境配慮行動の規定因の分析 一大学内の環境への取り組みに着目して一
}

\author{
寺村 友里 $^{1} \cdot$ 村上 一真 ${ }^{1 *}$ \\ 1滋賀県立大学 環境科学部 環境政策・計画学科（†522-8533 滋賀県彦根市八坂町2500） \\ *E-mail: murakami.k@ses.usp.ac.jp
}

\begin{abstract}
大学生の日常生活における環境配慮行動の規定因を明らかにするモデルを構築し, 大学内の環境への取 り組み（大学での環境の授業, 大学の環境への取り組み, 学内の環境団体の環境への取り組み) が, 大学 生の環境配慮行動（環境配慮商品の購入，不要なものを買わない，節電）に与える影響を，2つの大学へ の質問票調査データを用いた共分散構造分析により明らかにするとともに，大学の違いによるそれら影響 の差異を多母集団同時分析により明らかにした。結果, 大学での環境の授業は間接的に学生の環境配慮行 動を促進していること, 滋賀県立大学での環境団体の取り組みは, 広島修道大学に比べて学生の環境配慮 行動に強い影響を与えていることなどが明らかになった。
\end{abstract}

Key Words : Pro-environmental behavior, structural equation modeling, determinants, university

\section{1. 背景・目的}

地球規模での環境問題の改善のために，環境に配慮し

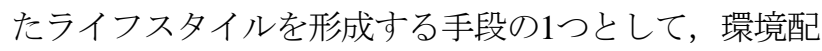
慮行動の促進への関心が高まっている．ただ，個人の消 費行動等に法的な制約をかけて，強制的に環境配慮行動 を促すことは現実には難しい.また，各人が環境配慮行 動は必要だと認識していても，実践へと結びつかないこ とが課題となっている1).

環境省(2012) 2)の「環境にやさしいライフスタイル調 査」によると，環境問題への取り組みに対する意識は， 年代別に見ると 20 代が最も低く, 高年世代が高い. また, 職業別に見た場合でも, 学生が最も低い項目が多く, 環 境配慮行動の実施意向でも20代が最も低い項目が目立つ. このように，消費者の中でも，特に若者や学生は環境へ の意識や環境配慮行動を実施する割合が低いといえる.

大学という組織に属している学生に対し, 環境配慮行 動を促進する方策にはどのようなものがあるだろうか. 宮崎ら(2010) $)^{31}$ は，大学における環境教育として，大学で 行われている授業, キャンパス内の建物・設備における 環境配慮, 学生主体の活動を挙げ，跡見学園女子大学の 環境への取り組みの現状を明らかにしている．また，塚 脇ら(2007) $)^{4)}$ では，大学生を対象に，ゴミ分別行動，塩化 ビニールの不買行動, 洗阂適量使用行動, 過剩包装の拒
否，リサイクル活動などの環境配慮行動についての要因 連関モデルを，重回帰分析によって検証している．要因 連関モデル5)とは，環境問題への関心や環境に配慮した いという意識を持ちながらも，実践行動につながらない という，態度と行動の不一致を明らかにしようとするモ デルである.

環境配慮行動を促進，または抑制する要因を解明する ことは，効率的な環境配慮行動の促進一と繋がる，その ため, 環境配慮行動の規定因の解明は重要な課題である. 環境配慮行動の規定因を探る研究は, 社会心理学の分野 を中心に多くなされているが，宮崎ら(2010) ${ }^{3)}$ で取り上げ られているような大学内の環境への取り組みが, 大学生 の環境配慮行動に対してどのような影響を与えているか をモデル化し，明らかにした研究はない。

本研究では, 大学内の環境への取り組みを, 大学での 環境の授業, 大学の環境への取り組み, 学内の環境団 体・環境サークルの環境への取り組みの3つで捉え，こ れらの大学生の環境配慮行動への影響を, モデル分析に より明らかにする。

また，大学生を対象とした先行研究では，検証を1つ の大学で行っているか, 複数の大学を対象としていても, 大学間の規定因の比較は行われていない. したがって, 本研究では研究対象を滋賀県立大学（以下，県大）とし， 広島修道大学（以下, 修大）との比較検討を行うことで, 
県大生の環境配慮行動の規定因の特性等を明らかにする。

県大は1995年に設置された公立大学で，環境科学部，

工学部, 人間文化学部, 人間看護学部によって構成され

ている. なかでも環境科学部では, 「環境問題を自然科 学と社会科学の両側面から深く追求した教育・研究を行 うことにより，私たちをとりまく環境を総合的に把握で きる能力と, 環境問題を解決し, 環境を創造するための 高度な専門知識と技術を併せ持った人材を養成する」こ とを教育目標に掲げているの。前述したように，若者や 学生は環境一の意識や行動の水準が低いとされているが, 環境学部が存在し，以上のような教育目標を掲げている 県大における大学内の環境への取り組みが, 学生にどの ような影響を与えているかを検証する.

ここで，比較対象とした修大の選定手順を示す．まず 県大と同様に, 他学部の学生でも理解しや寸い文系向け の授業が開講され, 文系の環境学部が存在する 8 大学を 候補とした. 次に, その8校のうち6校は県大の環境学部 の学生数とに開きがあったため除外し, 残り2校のうち, 学生への質問票調査が可能であった修大を選定した.

本研究は, 大学生の日常生活における環境配慮行動の 規定因を明らかにするモデルを構築し，大学内の環境一 の取り組みが，大学生の環境配慮行動にどのような影響 を与えているかを明らかにする. 加えて, 大学の違いに よるそれらの影響の差異を考察する.これらにより, 県 大生の環境配慮行動促進に資することが期待される.

\section{2. 研究方法}

まず，先行研究やヒアリングをもとに，大学内の環境 への取り組みに関する要因を組み込んだ，大学生の環境 配慮行動の規定因を明らかにする仮説モデルを構築する。 次に, 両大学の学生に質問票調査を実施し, そのデータ を用いて仮説モデルを検証する.

\section{(1) 仮説モデルの構築}

\section{a) 環境配慮行動の設定}

本研究では, 環境配慮行動の設定において, 大学生で も日常的に実行しや寸く，かつごみ分別のように住んで いる自治体によって差が出ず，個人に罰則などの制約の かからない行動を選定する. 花田(2005) ${ }^{7}$ が大阪産業大学 の環境学部の学生に行った調査では, 環境配慮的な購買 行動の実行度として，「買う時に本当に必要から゙うか考 えている」「詰め替え容器に入った製品を選んでいる」 の項目の得点が非常に高く, 「再生紙で作られたノート や便せんを選んでいる」「消費電力の少ない家電製品を 選んでいる」「耐久消費財はできるだけ修理して使うよ うにしている」の項目がそれに続いた. 家電製品の購入
や修理は，一人暮らしか家族暮らしかの居住形態の違い によって差が出るため対象外とし, 本研究では, 環境配 慮行動として「不要なものを買わない」「環境配慮商品 の購入」を設定した．また，誰でも行うことができ，多 くの先行研究でとり上げられてきた「節電」も環境配慮 行動に加えた.

「環境配慮商品の購入」は, グリーンコンシューマー 研究会のグリーン購入度チェックの項目 ${ }^{8)}$ を参考に,

「環境ラベルのついている商品」「詰め替えのできる商 品」「無添加などの安全な商品」の3つの商品の購入状 況で測定する。「節電」は「自室でエアコンを28度に設 定している(夏)」「自室でこまめな消灯をしている」

「自室でプラグオフをしている」の3つの行動を設定し た. 自室と限定しているのは, 一人暮らしと家族暮らし との差を極力無くすためである. なお「不要なものを買 わないははその1つの質問で測定する.

以上より, 本研究では「環境配慮商品の購入」「不要 なものを買わない」「節電」を環境配慮行動として設定 し, 複数の下位尺度により, その水準の測定を行う。

\section{b) 規定因の検討}

Ajzen(1991) ${ }^{9}$ の計画的行動理論, Schwartz(1977) ${ }^{10)}$ の規範

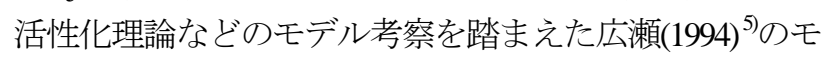
デルをベースに，小池ら(2003) ${ }^{11)}$ ，三阪(2003) ${ }^{12)}$ の研究を 踏まえて, 規定因を検討する.

広瀬(1994) $)^{5}$ は，図-1のような環境配慮行動の要因連関 モデルを提起している.このモデルは, 環境配慮行動に 至るまでの意思決定の過程を, 環境問題に対して何らか の貢献をしたいという態度である「環境にやさしくとの 目標意図」を形成するまでと，具体的な行動場面におい て実行しようとする意図である「環境配慮的な行動意 図」を形成するまでの2段階として捉え，それぞれの段 階に影響を及ぼす規定因との関係を示したものである.

目標意図は, 環境問題の深刻さの評価である「環境リ スク認知」, 環境問題への個人の責任感である「責任帰 属認知」，行動することで環境問題が解決できるという 有効感である「対処有効性認知」の3つの環境認知で形 成されている，また，行動意図は，行動害行に関する制 約や容易さに関する評価である「実行可能性評価」, 個

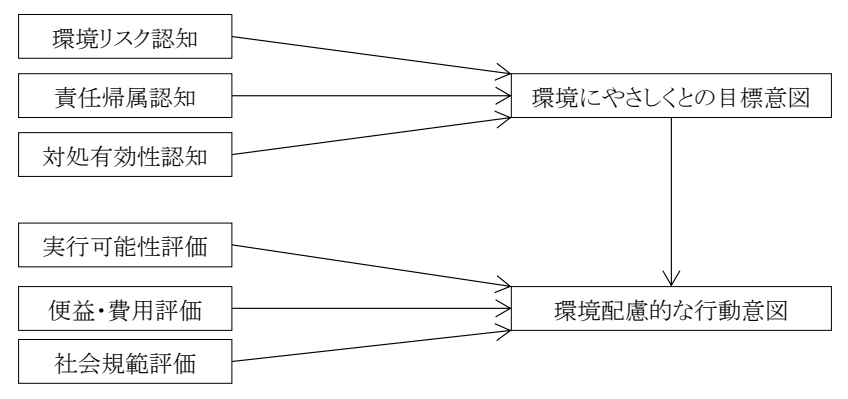

図-1＼cjkstart広瀬(1994)の要因連関モデル 
人的便益と個人的コストの評価である「便益・費用評 価」，主観的規範に相当する地域社会などの準拠集団か らの期待や圧力である「社会規範評価」の $3 つ の$ 行動評 価で形成されている.

また，小池ら $(2003){ }^{11}$ は環境問題を知っていても必ず しも行動に結びつくわけではないという，知識と行動の 不一致に注目することによって, 人々が環境問題を知っ ている状態から環境配慮行動に移すまでには，「知識」

「関心」「動機」「行動意図」という心理段階を経ると 捉えた. さらに，三阪(2003) ${ }^{12}$ は知識の習得も1つの目標 とする環境教育の視点から, 小池ら $(2003)^{11)}$ の心理段階 の進行と，広瀬(1994) $)^{5)}$ 要因連関モデルの態度と行動に 影響を及ぼす6つの規定因をもとに，新たに知識獲得を 考慮に入れた心理プロセスモデルを提起した.つまり， 外的情報源を通じて学んだ情報をいかに理解するかとい う「認知」の段階を，小池ら $(2003)^{11}$ が定義した「知 識」の段階の前に定義した. さらに，小池ら(2003) ${ }^{11)}$ で は明示されていなかった，広瀬(1994) ${ }^{5}$ が仮定した態度や 行動意図を促進あるいは抑制する6つの規定因を，小池 ら $(2003)^{11)}$ の各心理段階と関連づけた。具体的には,

「関心」や「動機」に影響を及ぼす規定因として「危機 感」「責任感」「有効感」を，「行動意図」に影響を及 ぼす規定因として「実行可能性評価」「費用便益評価」

「社会規範評価」を関連させている.

\section{c) 仮説モデルの構築}

以上を踏まえて，仮説モデルを図-2のように構築した。 (12環境配慮行動への直接要因は, 広瀬(1994) $)^{5}$ のモデル で扱われている要因を踏まえ，図-2および表-1の(6)〜(11) とした.「規範感」は，自分の属する集団の中で環境配 慮行動がどのように捉えられているかに関する評価であ る. ここで，西川ら(2001) ${ }^{13)}$ での自分の行動と身近な人 の行動が一致していると個人は認識する傾向があるとの 研究結果を踏まえ, 身近な人の行動と自分の行動への期 待を区別し，「他者追随」と「他者評価」を設定した.

また，本研究では実行のハードルが低いとされている基 本的な3つの環境配慮行動を選定しているため, 広瀬 (1994) 5)の図-1で示された実行可能性評価に関する要因は 除いた。 なお，(8)有効感，(9)スト感，規範感の(10他者 追随，(11)他者評価は，環境配慮行動ごとに異なると想定

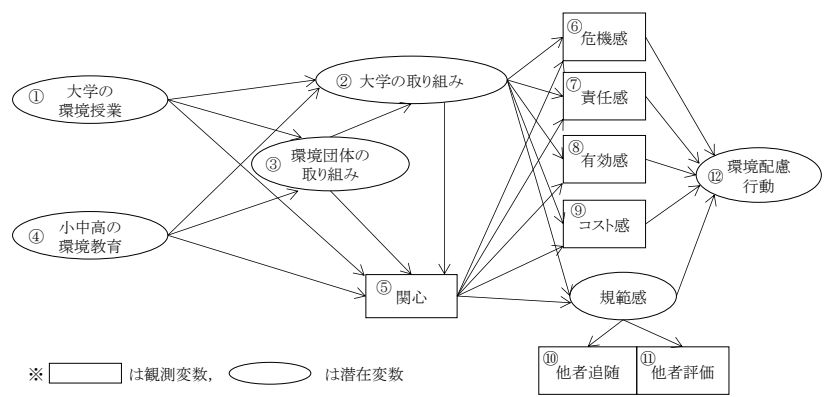

図-2 仮説モデル
されるため，3つの環境配慮行動それぞれに関して把握 する.

次に，前述した直接要因に影響を与えると想定される 間接要因として，図-2および表-1の(1)〜(5)の要因を設定 した.これらは3つの環境配慮行動に共通の要因となる。 本研究では，大学内の環境への取り組みが，直接要因 にどのような影響を与えているかを明らかにするために, (1)大学での環境の授業への評価（以下，大学の環境授 業），(2)大学の環境への取り組み評価（以下，大学の取 り組み），(3)環境団体・環境サークルの環境への取り組 み評価（以下，環境団体の取り組み）を間接要因に設定 した. なお，各大学および各大学の環境団体の節電と $3 R$ を中心とした環境への取り組み概要は表-2のとおりであ る.

また，三阪 $(2003)^{12)}$ の認知・行動心理プロセスモデル の「外的情報源 $\longrightarrow$ 認知 $\longrightarrow$ 知識 $\rightarrow$ 関心」に注目し, 知識の 供給源として行動への有用性に関わる(4)小中高の環境教 育，(5)環境問題への関心度（以下，関心）を間接要因に 加えた.この環境教育を小学校〜高校までに設定してい

表-1 本研究で仮定した規定因

\begin{tabular}{|c|c|c|c|c|}
\hline \multicolumn{3}{|c|}{ 要因名 } & 内容 & $\begin{array}{l}\text { 設問 } \\
\text { 番号 }\end{array}$ \\
\hline \multirow{5}{*}{$\begin{array}{l}\text { 間 } \\
\text { 接 } \\
\text { 要 }\end{array}$} & \multicolumn{2}{|c|}{ (1)大学の環境授業 } & $\begin{array}{l}\text { 自大学の環境の授業への評価と } \\
\text { して, 授業の理解度, 満足度, } \\
\text { 難易度 }\end{array}$ & $\begin{array}{l}\mathrm{Q} 1 \sim \\
\mathrm{Q} 3\end{array}$ \\
\hline & \multicolumn{2}{|c|}{ (2)大学の取り組み } & $\begin{array}{l}\text { 自大学が行っている節電, 3R の } \\
2 \text { つの取り組みへの渪足度 }\end{array}$ & $\begin{array}{l}\text { Q4, } \\
\text { Q5 }\end{array}$ \\
\hline & \multicolumn{2}{|c|}{$\begin{array}{l}\text { (3)環境団体の } \\
\text { 取り組み }\end{array}$} & $\begin{array}{l}\text { 自大学内の環境団体が行ってい } \\
\text { る節電, 3R の } 2 \text { つの取り組みへ } \\
\text { の満足度 }\end{array}$ & $\begin{array}{l}\text { Q6, } \\
\text { Q7 }\end{array}$ \\
\hline & \multicolumn{2}{|c|}{ (4)小中高の環境教育 } & $\begin{array}{l}\text { 小学校, 中学校, 高校における } \\
\text { 環境教育が自身の役に立ってい } \\
\text { るか }\end{array}$ & $\begin{array}{l}\text { Q8 } \\
\text { Q10 }\end{array}$ \\
\hline & \multicolumn{2}{|l|}{ (5)関心 } & 環境問題に対して関心があるか & Q11 \\
\hline & \multicolumn{2}{|c|}{$\begin{array}{l}\text { 6)危機感 } \\
\text { (=環境リスク認知) }\end{array}$} & 環境問題に危機感があるか & Q12 \\
\hline & \multicolumn{2}{|c|}{\begin{tabular}{|l|} 
7)責任感 \\
(=責任帰属認知)
\end{tabular}} & $\begin{array}{l}\text { 環境問題を解決する責任が自分 } \\
\text { にもあるか }\end{array}$ & Q13 \\
\hline \multirow{4}{*}{ 直 } & \multicolumn{2}{|c|}{$\begin{array}{l}\text { 8)有効感 } \\
\text { (=対処有効性認知) }\end{array}$} & $\begin{array}{l}\text { 対策が環境問題に有効であるか } \\
\text { (環境配慮行動ごと) }\end{array}$ & $\begin{array}{l}\text { Q14, } \\
\text { Q18, } \\
\text { Q22 }\end{array}$ \\
\hline & \multicolumn{2}{|c|}{$\begin{array}{l}\text { (9)コスト感 } \\
\text { (=便益・費用評価) }\end{array}$} & $\begin{array}{l}\text { 対策を行うことによって費用面 } \\
\text { でメリットがあるか(環境配慮 } \\
\text { 行動ごと) }\end{array}$ & $\begin{array}{l}\text { Q15, } \\
\text { Q19, } \\
\text { Q23 }\end{array}$ \\
\hline & \multirow{2}{*}{$\begin{array}{l}\text { 規範感 } \\
(=\text { 社会規 } \\
\text { 範評価 })\end{array}$} & $\begin{array}{l}\text { (10)他者 } \\
\text { 追随 }\end{array}$ & $\begin{array}{l}\text { 環境配慮行動を周囲の人がして } \\
\text { いるか(環境配慮行動ごと) }\end{array}$ & $\begin{array}{l}\text { Q16, } \\
\text { Q20, } \\
\text { Q24 }\end{array}$ \\
\hline & & $\begin{array}{l}\text { (111)他者 } \\
\text { 評価 }\end{array}$ & $\begin{array}{l}\text { 環境配慮行動は周囲の人から評 } \\
\text { 価されるか(環境配慮行動ごと) }\end{array}$ & $\begin{array}{l}\text { Q17, } \\
\text { Q21, } \\
\text { Q25 }\end{array}$ \\
\hline \multirow{3}{*}{$\begin{array}{l}\text { 環 } \\
\text { 境 } \\
\text { 配 } \\
\text { 行 } \\
\text { 動 }\end{array}$} & \multicolumn{2}{|c|}{$\begin{array}{l}\text { (12)環境配慮商品の } \\
\text { 購入 }\end{array}$} & $\begin{array}{l}\text { 環境ラベルのついている商品, } \\
\text { 詰め替えのできる商品, 無添加 } \\
\text { など安全な商品の購入 }\end{array}$ & $\begin{array}{l}\text { Q26 } \\
\sim \\
\text { Q28 }\end{array}$ \\
\hline & \multicolumn{2}{|c|}{\begin{tabular}{|l} 
12)不要なものを \\
買わない
\end{tabular}} & $\begin{array}{l}\text { 買い物のときに不要なものを買 } \\
\text { わないようにしている }\end{array}$ & Q29 \\
\hline & \multicolumn{2}{|l|}{ (12)節電 } & $\begin{array}{l}\text { エアコンを } 28 \text { 度に設定している } \\
\text { (夏), こまめな消灯をしてい } \\
\text { る, プラグオフをしている }\end{array}$ & $\begin{array}{l}\text { Q30 } \\
\sim \\
\text { Q32 }\end{array}$ \\
\hline
\end{tabular}

※直接要因の（ ）内は広瀬(1994)の要因連関モデルでの表記 
表-2 各大学および各大学の環境団体の環境への取り組み概要（節電，3R）

\begin{tabular}{|c|c|c|}
\hline \multirow{2}{*}{$\begin{array}{l}\text { 大 } \\
\text { 学 }\end{array}$} & 県大 & $\begin{array}{l}\text { • クールビズの実施（5～10 月），太陽光パネルの設置，空にフィルムの採用（断熱，光の遮断），空調を工夫した設計の建物，電 } \\
\text { 気・ガス使用量削減，水使用量削減 } \\
\text { •ゴミの削減，分別の推進，グリーン購入の推進 }\end{array}$ \\
\hline & 修大 & $\begin{array}{l}\text { •クールビズの実施（5〜10月），LED 照明の採用及び不必要な照明器具の撤去，冷・暖房温度の省エネ設定，空調稼働時間の短縮，自 } \\
\text { 販機の省エネタイプの導入，照明の消し忘れ巡回，電気使用量削減，HPでの節電を呼びが（講義関係） } \\
\text { • eco検定，3R・低炭素社会検定試験の単位認定 }\end{array}$ \\
\hline \multirow[t]{2}{*}{ 環 } & 県大 & 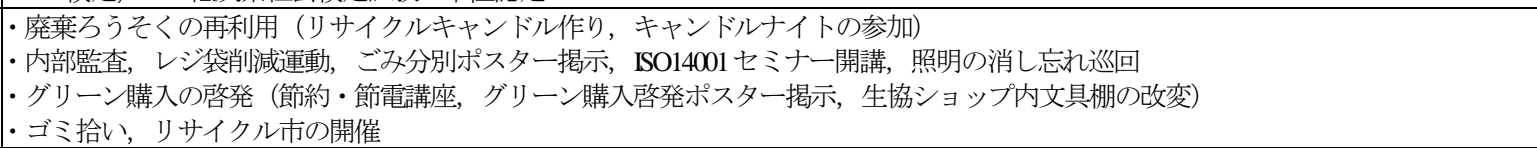 \\
\hline & 修大 & ••ゴミ拾い \\
\hline
\end{tabular}

るのは，保育園・幼稚園の環境教育は記憶に残つていな いと想定されること，大学の環境教育は「大学の環境授 業」と重複すると考えられるためである.

なお，間接要因の構造に関して，図-2のように，「小 中高の環境教育」と「大学の環境授業」を，「関心」を 喚起させる要因として，また「大学の取り組み」と「環 境団体の取り組夕」評価のための外部情報源として位置 づけ，これらの関係をパスで結んだ.

また，「環境団体の取り組夕」は，環境団体への支 援を行う大学の評価にもつながると想定されるため,

「大学の取り組み」にパスを引いた. さらに，それらの 取り組みの認知が「関心」を喚起させると想定し，「関 心」へのパスを引いた。

最後に，環境配慮行動は，先に示したように，表-1の (12)の「環境配慮商品の購入」「不要なものを買わな い」「節電」の3つとし，各行動別に商品モデル，不要 モデル，節電モデルの3つのモデルを構築し，分析する.

\section{(2) 分析方法}

県大，修大の学生への質問票調査のデータを用いて, 共分散構造分析の多母集団同時分析を行う。多母集団 同時分析は，複数の母集団における同一の因子構造の 検証や因果関係の差異を検証する手法である。ここで は，2つの大学の母集団に対して，モデル構造の大学ご との妥当性を検証するとともに，大学間のパス係数の 大きさの違いを検証する.

\section{(3) 質問票の調査項目}

調査項目は，表-1 の右欄「設問番号」に示したよう に，仮説モデルの各要因に沿って設定した。具体的な 設問内容は表-3のとおりである.

これらの項目は基本的に[強くそう思う，そう思う， ややそう思う，あまりそう思わない，そう思わない， 全くそう思わない]の6段階評価とした．ただし，「大 学の環境授業」「小中高の環境教育」を受けていない 可能性があるため，これらの設問では，6段階評価に加 え，[該当しない］を設定した。また，環境配慮行動の 「不要なものを買わない」「節電」も，一人暮らしか 家族暮らしかの違いなどであてはまらない可能性が考
えられるため，同様に[該当しない]の選択肢を設けた.

さらに，モデル分析で用いる表-3 の項目以外に，属 性や現状を把握する項目として，学部，同居人数，一ヶ 月で自由に使える金額，大学の取り組みの認知度，環境 団体の取り組みの認知度なども尋ねた。認知度は，6段 階評価[強くそう思う〜全くそう思わない]とした。

\section{(4) 質問票調査の方法}

県大，修大の学生に対し，質問票調査を実施した。 県 大では 2014年7月 22 日から 8 月 6 日にかけて県大内食 堂にて学生に直接配布し, 食堂入口に質問票回収 BOX を設けて回収した。修大では教員に依頼し，2014 年 11

表-3 質問票調査項目

\begin{tabular}{|c|c|c|}
\hline $\begin{array}{l}\text { 分 } \\
\text { 類 }\end{array}$ & $\begin{array}{l}\text { 設問 } \\
\text { 番号 }\end{array}$ & 設問文 \\
\hline \multirow{11}{*}{$\begin{array}{l}\text { 間 } \\
\text { 接 } \\
\text { 要 } \\
\text { 因 }\end{array}$} & Q1 & 環境の授業の理解度は高い \\
\hline & Q2 & 環境の授業の満足度は高い \\
\hline & Q3 & 環境の授業の難易度は適切である \\
\hline & Q4 & 大学が行っている節電に満足している \\
\hline & Q5 & 大学が行っている3Rに満足している \\
\hline & Q6 & 学内の環境団体が行っている節電に満足している \\
\hline & Q7 & 学内の環境団体が行っている3Rに満足している \\
\hline & Q8 & 小学校での環境教育は役に立っている \\
\hline & Q9 & 中学校での環境教育は役に立っている \\
\hline & Q10 & 高校での環境教育は役に立っている \\
\hline & Q11 & 環境問題に関心がある \\
\hline \multirow{14}{*}{$\begin{array}{l}\text { 直 } \\
\text { 接 } \\
\text { 要 } \\
\text { 因 }\end{array}$} & Q12 & 環境問題に危機感がある \\
\hline & Q13 & 環境問題を解決する責任は自分にもある \\
\hline & Q14 & 不要なものを買わないことは環境問題に有効である \\
\hline & Q15 & 不要なものを買わないことでお金が安く済む \\
\hline & Q16 & 不要なものを買わないことは周りがやっている \\
\hline & Q17 & 不要なものを買わないことは周りに評価される \\
\hline & Q18 & 環境配慮商品を買うことは環境問題に有効である \\
\hline & Q19 & 環境配慮商品を買うことでお金が安く済む \\
\hline & Q20 & 環境配慮商品を買うことは周りがやっている \\
\hline & Q21 & 環境配慮商品を買うことは周りに評価される \\
\hline & Q22 & 節電をすることは環境問題に有効である \\
\hline & Q23 & 節電をすることでお金が安く済む \\
\hline & Q24 & 節電をすることは周りがやっている \\
\hline & Q25 & 節電をすることは周りに評価される \\
\hline \multirow{7}{*}{ 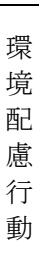 } & Q26 & 環境ラベルのついている商品を購入する \\
\hline & Q27 & 詰め替えのできる商品を購入する \\
\hline & Q28 & 無添加など安全な商品を購入する \\
\hline & Q29 & 買い物のときに不要なものを買わないようにしている \\
\hline & Q30 & 自室でエアコンを 28 度に設定している(夏) \\
\hline & Q31 & 自室でこまめな消灯をしている \\
\hline & Q32 & 自室でプラグオフをしている \\
\hline
\end{tabular}


月 17 日から 12 月 4 日にかけて質問票調査を行った．人 間環境学部, 商学部の授業の終わりに 5 10 分程度で学 生に回答してもらい, 回収した. また, 修大での調査で は, 先に調査を行った県大の環境学部と他学部学生の回 収比率と合わせるように配布数を調整した. 質問票の回 収結果は, 県大では 445 枚配布, 回収数は 364 枚, 回収 率は $81.8 \%$ となった，修大では 350 枚配布し，回収数は 288 枚，回収率は $82.3 \%$ となった。

回答者の属性をみると, 環境学部と他学部の比率は, 県大では環境科学部 $26.9 \%$, 他学部 73.1\%に対し, 修大 では人間環境学部 $31.9 \%$, 他学部 $67.4 \%$ となり, 県大よ りも修大が環境学部の比率が若干高い結果となった.

居住形態は，県大は一人暮らしの比率は $39.6 \%$, 家族 暮らしは $60.4 \%$ となった. 一方，修大では一人暮らしは $27.1 \%$ ，家族暮らしは $72.2 \%$ となった。一か月で自由に 使える金額は，県大で 1 万円未満が $24.2 \% ， 3$ 万円未満 が 41.5\%，5 万円未満が 24.5\%，10 万円未満が $8.2 \% ， 10$ 万円以上が $1.4 \%$ となった．修大では 1 万円未満が $14.9 \%$, 3 万円未満が $35.4 \% ， 5$ 万円未満が $28.1 \% ， 10$ 万円未満が 16.0\%，10 万円以上が 4.9\%となった. 以上の結果より, 県大の学生は修大の学生よりも一人暮らしの比率が高く, 一か月で自由に使える金額も修大の学生よりも少ないと いえる.

また，節電と $3 R$ についての「大学の取り組み」と 「環境団体の取り組み」をどの程度知っているかを 6 段 階評価で尋ねた. 結果, 両大学とも約 6 割がいずれの項 目においても[あまりそう思わない][そう思わない][全 くそう思わない］と否定的な回答をした（表-4）。つま り, 表-2 に示したような大学内の環境への取り組みに 対する認知度は低く, 大学側が行っている取り組みと環 境団体の取り組みとの区別がついてない可能性もある.

なお節電と $3 \mathrm{R}$ についての大学およひ環境団体の取り 組みの満足度（表-3の Q4 Q7）と，表-4 のそれぞれの 認知度の相関係数はいずれも $5 \%$ 水準で有意である.

\section{3. 結果および考察}

\section{（1） データ選定}

表-3 に示した設問ごとの記述統計は表-5 である. 分 析で用いるデータの選定のため, 天井効果とフロア効果 を確認した. 結果, Q15, Q18, Q22, Q23, Q27 の項目 で天井効果（平均+標準偏差が最大值 6 を超える）が見 られたため, 分析から除外した.

県大と修大での各項目の平均の差をみると, 表-5より, 有意な差があったのはQ1, Q9, Q10, Q16, Q17, Q19, Q20，Q21，Q26，Q28，Q32であり，すべての項目で修 大が高い.
表-4 大学と環境団体の取り組みの認知状況

\begin{tabular}{|c|c|c|c|c|c|c|c|}
\hline & & \multicolumn{2}{|c|}{ 肯定 } & \multicolumn{2}{|c|}{ 否定 } & \multicolumn{2}{|c|}{ 無回答 } \\
\hline \multirow{4}{*}{$\begin{array}{l}\text { 県 } \\
\text { 大 }\end{array}$} & 節電（大学の取り組み） & & & 57.7 & $\%$ & 3.3 & $\%$ \\
\hline & 3R (大学の取り組み) & 35.2 & $\%$ & 62.6 & $\%$ & 2.2 & $\%$ \\
\hline & 節電（環境団体の取り組み） & 36.3 & & 61.5 & $\%$ & 2.2 & $\%$ \\
\hline & (環境団体の取り組み) & 35.2 & $\%$ & 61.8 & $\%$ & 3.0 & $\%$ \\
\hline \multirow{4}{*}{$\begin{array}{l}\text { 修 } \\
\text { 大 }\end{array}$} & 節電（大学の取り組み） & 36.5 & & 61.1 & $\%$ & 2.4 & $\%$ \\
\hline & (大学の取り組み) & 38.2 & $\%$ & 60.4 & $\%$ & 1.4 & $\%$ \\
\hline & 節電（環境団体の取り組み） & 38.5 & $\%$ & 59.7 & $\%$ & 1.7 & $\%$ \\
\hline & (環境団体の取り組み) & 37.2 & $\%$ & 61.1 & $\%$ & 1.7 & $\%$ \\
\hline
\end{tabular}

表-5 記述統計

\begin{tabular}{|c|c|c|c|c|c|}
\hline \multirow{2}{*}{$\begin{array}{l}\text { 設問 } \\
\text { 番号 }\end{array}$} & \multicolumn{2}{|c|}{ 県大 $(\mathrm{N}=364)$} & \multicolumn{2}{|c|}{ 修大 $(\mathrm{N}=288)$} & \multirow{2}{*}{$\begin{array}{l}\text { 平均 } \\
\text { の差 }\end{array}$} \\
\hline & 平均 & 標準偏差 & 平均 & 標準偏差 & \\
\hline Q1 & 3.75 & 1.03 & 3.95 & 1.02 & $*$ \\
\hline Q2 & 3.73 & 1.10 & 3.88 & 1.06 & \\
\hline Q3 & 4.00 & 0.94 & 3.91 & 1.02 & \\
\hline Q4 & 3.33 & 1.15 & 3.33 & 1.16 & \\
\hline Q5 & 3.39 & 1.06 & 3.35 & 1.18 & \\
\hline Q6 & 3.24 & 1.09 & 3.29 & 1.24 & \\
\hline Q7 & 3.24 & 1.10 & 3.28 & 1.21 & \\
\hline Q8 & 4.10 & 1.18 & 4.26 & 0.99 & \\
\hline Q9 & 4.03 & 1.13 & 4.27 & 1.02 & $* *$ \\
\hline Q10 & 4.06 & 1.12 & 4.29 & 1.02 & $* *$ \\
\hline Q11 & 4.36 & 1.02 & 4.38 & 0.98 & \\
\hline Q12 & 4.33 & 1.08 & 4.48 & 1.06 & \\
\hline Q13 & 4.44 & 1.01 & 4.50 & 0.95 & \\
\hline Q14 & 4.66 & 1.09 & 4.76 & 1.06 & \\
\hline Q15 & 5.49 & 0.71 & 5.13 & 1.00 & \\
\hline Q16 & 3.68 & 1.11 & 3.91 & 1.18 & $* *$ \\
\hline Q17 & 3.38 & 1.16 & 3.72 & 1.35 & $* *$ \\
\hline Q18 & 4.96 & 1.06 & 4.83 & 1.04 & \\
\hline Q19 & 3.06 & 1.30 & 3.88 & 1.37 & $* *$ \\
\hline Q20 & 3.22 & 1.13 & 3.90 & 1.21 & $* *$ \\
\hline Q21 & 3.55 & 1.27 & 3.98 & 1.30 & $* *$ \\
\hline Q22 & 5.24 & 0.94 & 5.02 & 1.01 & \\
\hline Q23 & 5.48 & 0.74 & 5.12 & 1.01 & \\
\hline Q24 & 4.26 & 1.26 & 4.40 & 1.16 & \\
\hline Q25 & 4.05 & 1.39 & 4.25 & 1.25 & \\
\hline Q26 & 3.04 & 1.23 & 3.57 & 1.26 & $* *$ \\
\hline Q27 & 5.04 & 1.11 & 4.78 & 1.16 & \\
\hline Q28 & 3.60 & 1.37 & 3.83 & 1.21 & $*$ \\
\hline Q29 & 4.43 & 1.19 & 4.41 & 1.20 & \\
\hline Q30 & 4.08 & 1.55 & 3.93 & 1.39 & \\
\hline Q31 & 4.38 & 1.34 & 4.33 & 1.32 & \\
\hline Q32 & 3.51 & 1.54 & 3.81 & 1.39 & $*$ \\
\hline
\end{tabular}

$* * p<0.01, \quad * p<0.05$

表-6 潜在変数と $\alpha$ 係数

\begin{tabular}{|c|c|c|c|c|}
\hline \multirow{2}{*}{\multicolumn{2}{|c|}{ 潜在変数 }} & 設問 & & \\
\hline & & 番号 & 県大 & 修大 \\
\hline \multicolumn{2}{|c|}{ 大学の環境授業 } & $\begin{array}{l}\text { Q1 } \\
\text { Q2 }\end{array}$ & 0.86 & 0.90 \\
\hline \multicolumn{2}{|c|}{ 大学の取り組み } & Q4 & 0.78 & 0.90 \\
\hline \multicolumn{2}{|c|}{ 環境団体の取り組み } & $\begin{array}{l}\text { Q6 } \\
\text { Q7 }\end{array}$ & 0.92 & 0.96 \\
\hline \multicolumn{2}{|c|}{ 小中高の環境教育 } & $\begin{array}{l}\text { Q8 } \\
\text { Q9 }\end{array}$ & 0.87 & 0.90 \\
\hline \multirow{3}{*}{ 規範感 } & 不要 & $\begin{array}{l}\text { Q16 } \\
\text { Q17 }\end{array}$ & 0.68 & 0.83 \\
\hline & 商品 & $\begin{array}{l}\text { Q20 } \\
\text { Q21 }\end{array}$ & 0.69 & 0.79 \\
\hline & 節電 & $\begin{array}{l}\text { Q24 } \\
\text { Q25 }\end{array}$ & 0.76 & 0.76 \\
\hline \multirow{2}{*}{ 環境配慮 } & $\begin{array}{l}\text { 環境配慮商 } \\
\text { 品の購入 }\end{array}$ & $\begin{array}{l}\text { Q26 } \\
\text { Q28 }\end{array}$ & 0.67 & 0.75 \\
\hline & 節電 & $\begin{array}{l}\text { Q30 } \\
\text { Q31 } \\
\text { Q32 }\end{array}$ & 0.74 & 0.74 \\
\hline
\end{tabular}


なお，県大と修大の環境学部間の平均で $5 \%$ 水準で有 意な差があったのはQ14, Q19，Q20であった。また，県 大と修大の他学部間で5\%水準で有意な差があったのは Q1, Q9, Q10, Q16, Q17, Q19, Q20, Q21, Q25, Q26, Q28，Q32であった.

\section{（2）潜在変数の下位尺度の検証}

仮説モデルで設定した潜在変数の下位尺度の妥当性を, クロンバックの $\alpha$ 係数により確認した. 複数の設問から なる「大学の環境授業」「大学の取り組み」「環境団体 の取り組み」「小中高の環境教育」「規範感(不要, 商 品, 節電)」「環境配慮行動 (環境配慮商品の購入, 節 電)」の各大学の $\alpha$ 係数は表-6のとおりである. 県大の 「規範感(不要)」「規範感(商品)」「環境配慮商品の購 入」では0.7を若干下回ったが，0.65以上で比較的高い数 值であり，分析に際しては問題はないと判断した.

\section{(3) 仮説モデルの修正}

前項までで選定，加工したデータを用い，図-2 の仮 説モデルについて共分散構造分析の多母集団同時分析を 行い, 最尤法により解を求めた. 結果, 「大学の取り組 みー関心」のパスは有意にならなかったため，このパス を削除した.さらに，前述したように，「大学の取り組 み」と「環境団体の取り組み」は区別がついていない可 能性が示されたため，この2 項目は相関関係にあると設 定することで，仮説モデルを図-3 のように修正し，再 度分析を行った。

\section{(4) 分析結果}

両大学の商品モデル，不要モデル，節電モデルのそれ ぞれのパス係数 (標準化解), および大学間での各パス係 数の差の検証結果 (z值)，モデルの適合度を表-7に示す 天井効果が見られた項目を除いたため，3つのモデルに よって直接要因の有無に差があり, 存在しないパスは, 一と示した.

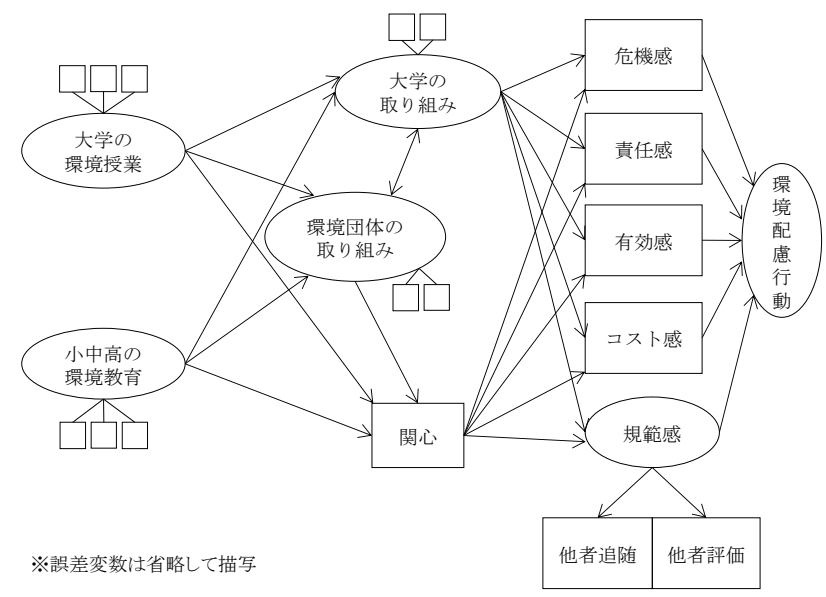

なお，全てのモデルで潜在変数から下位尺度の観測変 数へのパス係数はいずれも5\%水準で有意であった.

a) 商品モデル

モデルの適合度はCFI $=0.907$, RMSEA $=0.060$ となり，十 分な值と確認された.

まず，間接要因である「大学の環境授業」「小中高の 環境教育」「環境団体の取り組み」「大学の取り組み」

「関心」間のパスの結果を述べる. なお，これら5つの 間接要因はモデルによって異なる質問項目ではなく共通 な項目であり，表-7に示したように，3つのモデルによ って項目間のパスに大きな違いは見られなかった。した がって，以下の不要モデル，節電モデルでの説明は省く 両大学ともに，「大学の環境授業」は「環境団体の取 り組み」「大学の取り組み」「関心」に有意な影響を与 えている.「小中高の環境教育」も同様の結果である.

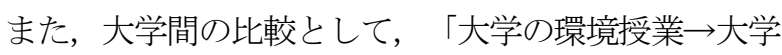
の取り組み」は修大の值が有意に大きい. 修大での環境 の授業は，大学の環境への取り組みへの認知をより高め ている結果となった. ただ，大学間の環境学部の人数比 率の違い, 環境学部以外で環境の授業を受けている人数 の違いも，この結果に影響を与えた可能性がある.

「環境団体の取り組み」は，県大では「関心」に有意 な影響を与えているが，修大では有意ではなかった。県 大の環境団体の環境への取り組みが「関心」の喚起につ ながる結果が示された. ただ，表-2に示したように学生 に節電や3Rの啓発活動をしている環境団体は県大が4団 体，修大が1団体であり，環境団体の取り組み内容だけ でなく，団体数の違いの影響もあると考えられる.

次に，直接要因から環境配慮行動へのパス係数の有意 性の違いを説明する，両大学ともに「責任感」「規範 感」が「環境配慮商品の購入」に有意な影響を与えてい る.人の目に触れやすい行動は，そうでない行動に比べ て規範感の影響が大きくなるとの研究結果があり4),

「環境配慮商品の購入」は人目に触れる行動であるため 「規範感」が有意になったと考えられる。また，「規範 感一環境配慮商品の購入」は，県大のパスが修大に比べ て有意に大きい.

県大ではこの $2 つ の$ 直接要因に加え，「コスト感」が 「環境配慮商品の購入」に有意な影響を与えているが, 「危機感」は有意ではない，逆に修大では「危機感」が 有意な影響を与えているが，「コスト感」は有意ではな い.この「コスト感」の結果の違いは，県大の学生は修 大の学生に比べて，一人暮らしが多い，一か月で自由に 使えるお金が少ないことが影響していると考えられる.

ここで，間接要因から「環境配慮商品の購入」への影 響を検証するため，表-8に総合効果(直接効果と間接効 果の和)を示した。直接効果は，それぞれの要因から環

図-3 修正モデル 
境配慮行動への直接のパスで示される. 間接効果は, そ れぞれの要因から環境配慮行動一間接的につながるパス を掛け合わせた数值の和で示される.

モデル構造として最も上流に設定した間接要因の「大 学の環境授業」と「小中高の環境教育」を比較すると, 両大学ともに「大学の環境授業」がより大きな影響を与 えている. また，直接要因に影響を与える位置に設定し た間接要因の「大学の取り組み」と「関心」との比較で は，両大学ともに「大学の取り組み」よりも「関心」が 大きな値となっている.

さらに，大学間の比較では，「大学の環境授業」はほ ぼ同じ值であり, その他の要因は県大が大きい.

\section{b) 不要モデル}

モデルの適合度はCFI $=0.938$, RMSEA $=0.050$ となり，十 分な值と確認された。直接要因から「不要なものを買わ ない」へのパス係数は, 両大学ともに「責任感」と「有 効感」が有意となっている.また，「危機感」と「規範 感」は両大学ともに有意にならなかった.

総合効果の結果は, 表-8より, 商品モデルと同様に, 両大学ともに「大学の環境授業」が「小中高の環境教 育」よりも「不要なものを買わない」に大きな影響を与 えている.「大学の取り組外」と「関心」の比較も同様 に「関心」が大きな値となった，なお，大学間の比較で は，「環境団体の取り組み」を除き，全ての項目で修大
が県大よりも大きい数值となった.

\section{c) 節電モデル}

モデルの適合度はCFI $=0.948$, RMSEA $=0.044$ となり，十 分な值と確認された。直接要因から「節電」へのパス係 数は, 両大学ともに「責任感」が有意となった。これは 東日本大震災以降，節電の必要性が叫ばれるようになっ たことと，7割以上の学生が環境情報を得る手段と回答 したテレビにおいて, 節電の呼びかけが行われているこ とが影響していると考えられる.

また，県大では「責任感」の他に，「危機感」が「節 電」の規定因となったが，「規範感」は有意ではない。 逆に修大では「危機感」が有意でなく，「規範感」が有 意となり，「規範感一節電」において，修大のパスが県 大に比べて有意に大きくなった。「危機感」の結果の違 いは，原発依存度が高く節電目標が相対的に厳しい関西 電力管内に立地する県大と, 中国電力管内の修大という 立地の違いが影響を与えている可能性がある.

総合効果の結果は, 表-8より, 商品モデル, 不要モデ ルと同様に, 両大学ともに「大学の環境授業」が「小中 高の環境教育」よりも「節電」に大きな影響を与えてい る.「大学の取り組み」と「関心」の比較も同様に「関 心」が大きな值となった。また, 大学間の比較では,

「環境団体の取り組み」を除き, 全ての項目で修大が県 大よりも大きい数值となった.

表-7 分析結果

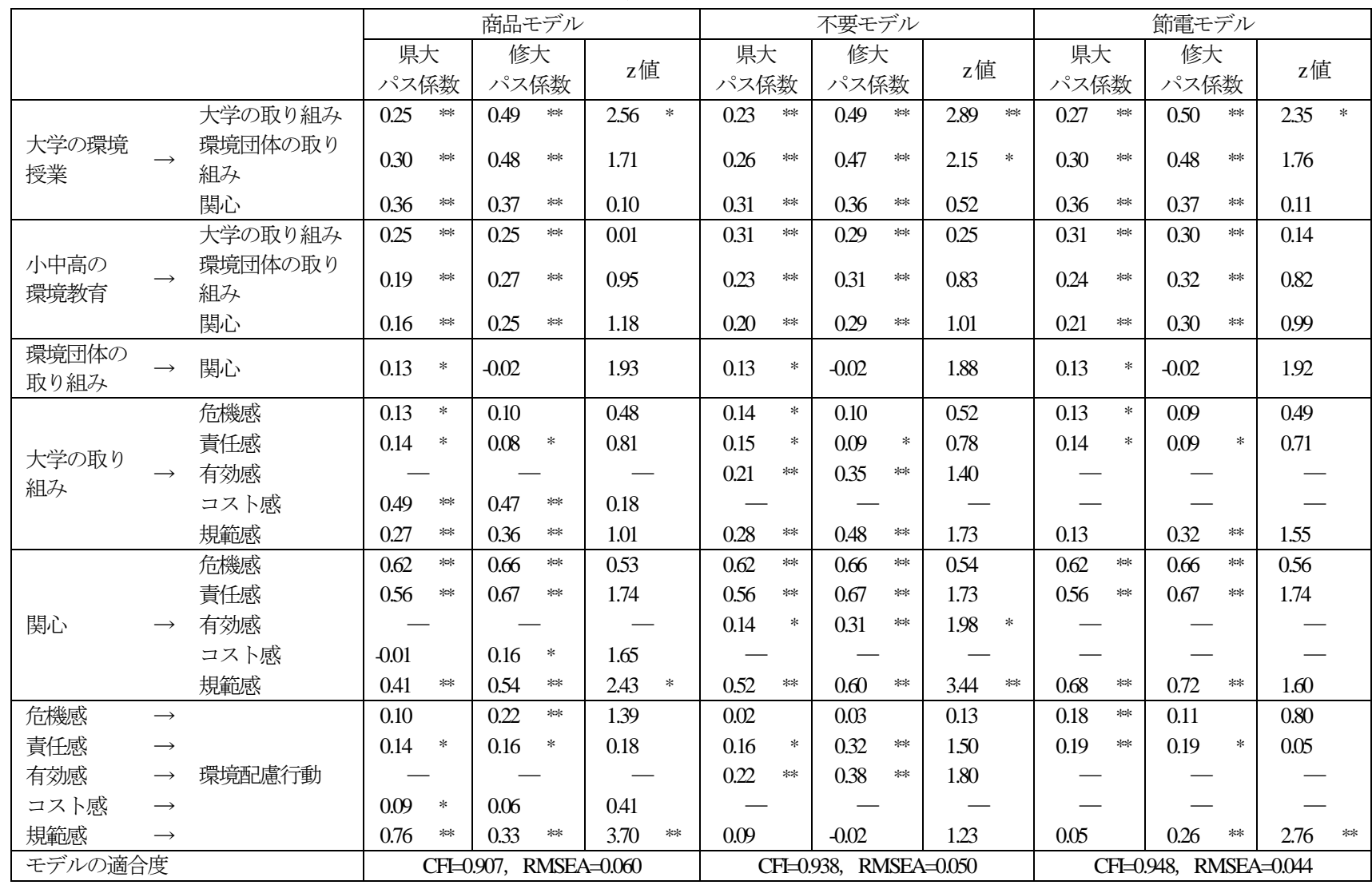

** $p<0.01, * p<0.05$, パス係数は全て標準化解, 一天井効果でデータを除外したことにより存在しないパス. 
表-8＼cjkstart環境配慮行動に係る標準化総合効果

\begin{tabular}{|c|c|c|c|c|c|c|c|}
\hline & \multicolumn{2}{|c|}{ 商品モデル } & \multicolumn{2}{|c|}{ 不要モデル } & \multicolumn{2}{|c|}{ 節電モデル } \\
\hline & & 県大 & 修大 & 県大 & 修大 & 県大 & 修大 \\
\hline \multirow{5}{*}{$\begin{array}{l}\text { 環 } \\
\text { 境 } \\
\text { 配 } \\
\text { 動 } \\
\text { 行 }\end{array}$} & $\leftarrow$ 大学の環境授業 & 0.25 & 0.25 & 0.07 & 0.15 & 0.11 & 0.17 \\
\hline & $\begin{array}{l}\leftarrow \text { 小中高の環境教 } \\
\text { 育 }\end{array}$ & 0.16 & 0.15 & 0.05 & 0.10 & 0.07 & 0.12 \\
\hline & $\begin{array}{l}\leftarrow \text { 環境団体の取り } \\
\text { 組み }\end{array}$ & 0.06 & -0.01 & 0.02 & -0.01 & 0.03 & -0.01 \\
\hline & $\leftarrow$ 大学の取り組み & 0.29 & 0.18 & 0.07 & 0.13 & 0.05 & 0.11 \\
\hline & $\leftarrow$ 関心 & 0.45 & 0.44 & 0.15 & 0.26 & 0.26 & 0.36 \\
\hline
\end{tabular}

なお，県大の「環境団体の取り組夕」は，「関心」へ のパスの有意性とともに，「環境団体の取り組み」から 環境配慮行動への総合効果は，3つの環境配慮行動す心゙ てで，修大よりも大きいことが確認された.

\section{(5) 考察}

ここでは先の修大との比較検討による県大の分析結果 をもとに，県大生の環境配慮行動の促進方策を考察する まず，直接要因から環境配慮へのパスの分析結果を述 ベる．商品モデルでは，「規範感」が「環境配慮商品の 購入」に最も強い影響を与えており，また修大と比べて も有意に大きい. 県大で環境配慮商品の購入を促進する には，規範感（他者追随，他者評価）を重視した方策が 効果的といえる. 例えば，大学生協ショップなどでの環 境配慮商品購入者ランキングの作成・貼付などが考えら れる.

また不要モデルでは，「責任感」「有効感」が直接要 因として有意となったが，「危機感」は有意にならなか った．商品モデルでも同様であった．これは，日々の一 個人の消費行動と，地球規模の環境問題は繋がりにくい ことを示唆している.

一方，節電モデルでは，「危機感」「責任感」が「節 電」に有意な影響を与えている。これは東日本大震災や それに伴う電力不足，テレビでの節電の呼びかけな゙か ら影響を受けているためと考えられる。 なお，3つのモ デルとも「責任感」は共通して有意な影響を与えており, 責任感を醸成させる方策の重要性が指摘できる．まさに これは，後述する大学の環境授業において，実際の環境 問題を題材にしながら当事者意識を持たせ，責任感を醸 成させていくことが可能であり，必要となる.

次に間接要因であるが，いずれのモデルでも，「大学 の環境授業」「小中高の環境教育」「環境団体の取り組 み」「大学の取り組み」「関心」は，間接的に環境配慮 行動にプラスの影響を与えている. 総合効果をみると， すべてのモデルで,「小中高の環境教育」よりも「大学 の環境授業」が大きな值となっている．この理由として， 授業内容以外に時間の経過による忘却も考えられるが, 大学生の間であれば「大学の環境授業」は環境配慮行動
を促す手段として有効であると言える.

加えて，県大の「環境団体の取り組み」は「関心」に 有意な影響を与えており，また環境配慮行動への総合効 果も修大より大きく，県大の環境団体の取り組みの重要 性が指摘できる．表-2に示したような活動をより積極的 に進めるとともに，環境団体・サークル所属以外の学生 も巻き込むような活動も，より活発化させていくことが 望まれる.

\section{4. おわりに}

本研究は, 若者や学生の環境への意識や行動の水準が 低いという問題関心から，大学生の日常生活における環 境配慮行動の規定因を明らかにするモデルを構築し，大 学内の環境への取り組み（大学での環境の授業, 大学の 環境への取り組み, 学内の環境団体の環境への取り組 み）が，大学生の環境配慮行動にどのような影響を与え ているかを明らかにした. 加えて，大学の違いによるそ れらの影響の差異を考察し, 県大生の環境配慮行動の促 進方策を考察した.

本研究の課題として，まず，質問票の選択肢が[強く そう思う〜全くそう思わないりで構成され，回答者の主 観に基づく評価であるため，実際の環境配慮行動の実施 度合いが異なる可能性があげられる。

2つ目は，大学の環境への取り組みと，環境団体の環 境への取り組みを区別できないまま回答した可能性があ ることである. 大学と環境団体の取り組み内容を質問票 に記載し，その上でそれぞれの認知度と満足度を尋ねる ことが改善策として考えられる.

3つ目は，質問票配布について，授業直後での配布と 食堂での配布による違いの可能性である。つまり，回答 環境の違いや，授業に出ていた学生と必ずしもそうとは 言えない学生の違いの可能性があり, 配布方法を統一す ることが望ましい.

4つ目は，本研究結果を踏まえて，より具体的な方策 を提示する必要がある。そのためには学部や個人属性な どの違いによる詳細な分析も必要となる. 大学内の環境 への取り組みは，それ自体が環境改善に貢献するととも に，間接的に学生の環境配慮行動を促進することから， 適切な方策提示による地球環境への波及効果は大きい.

\section{参考文献}

1) 広瀬幸雄 : 環境配慮行動の社会心理学一環境に向き合う 人間のこころと行動ーシリーズ 21 世紀の社会心理学, 北大 路書房, 2008.

2) 環境省 : 環境にやさしいライフスタイル実態調査 国民調 査の結果 平成 24 年度調査, http://www.env.go.jp/policy/kihon_kei 
kaku/lifestyle/h2504_01/chpt2-2.pdf

3）＼cjkstart宮崎正浩・長野基・高木庸・石渡尚子・吉村英子 : 大学 における持続可能性教育の現状と課題一跡見学園女子大 学における取組一，跡見学園女子大学マネジメント学部 紀要, Vol. 10,pp. 63-82,2010.

4) 塚脇涼太・戸塚唯氏・高本由紀子・小島奈々恵・樋口王 貴・深田博己 : 大学生の環境配慮行動意図の規定因一環 境配慮行動と規定因との要因連関モデルの検討一，広島 大学大学院教育学研究科紀要, Vol.56, pp.303-307,2007.

5）広瀬幸雄 : 環境配慮行動の規定因について，社会心理学 研究, 10(2), pp.44-55, 1994.

6) 滋賀県立大学 : 環境科学部, http://www.usp.ac.jp/japanese/campu s/gakubu/kankyo/

7) 花田眞理子 : 大学生の環境意識に関する考察一人間環境 学部都市環境学科の学生アンケート調査一, 大阪産業大 学人間環境論集, Vol.5,pp. 1-26,2005.

8) グリーンコンシューマー研究会 : GCチェック, http://www.g reen-consumer.org/old/gccheck.htm

9) Ajzen, I.: The theory of planned behavior. Organizational Behavior and Human Decision Process, Vol. 50, pp. 179-221, 1991.

10) Schwart, S. H.: Normative influences on altruism. In L. Berkowitz (Eds) Advances in Experimental Social Psychology, 10, Academic Press, New York, pp. 221-279, 1977.

11）小池俊雄・吉谷崇・白川直樹 - 澤田忠信 - 宮代信夫 ·井 上雅也 $\cdot$ 三阪和弘 $\cdot$ 町田勝 $\cdot$ 藤田浩一郎 $\cdot$ 河野真巳 $\cdot$ 増 田満・鈴木孝衣・深田伊佐夫・相ノ谷修通 : 環境問題に 対する心理プロセスと行動に関する基礎的考察，水工学 論文集，Vol.47,pp.361-366,2003.

12) 三阪和弘 : 環境教育における心理プロセスモデルの検討, 環境教育, 13(1), pp.3-14,2003.

13) 西川純・小松公之 : 社会的に構成される環境意識に関す る研究一上越教育大学学生及び, 上越地域市民を事例と して一，環境教育，11(1)，pp.55-62,2001.

(2015.4.7受付)

\section{A causal analysis of the determinants on pro-environmental behavior of university}

students: Focusing on the pro-environmental activities by the university

\section{Yuri TERAMURA $^{1}$ and Kazuma MURAKAMI ${ }^{1}$}

${ }^{1}$ School of Environmental Science, The University of Shiga Prefecture

We design a model to examine the role of the pro-environmental activities by the university (lecture of environment at the university, environment measure by the university organization, environment measure by an environment club of the university) to enhance the pro-environmental behavior of university students (purchase of eco-friendly goods, avoid the purchase of unnecessary goods, power-saving behavior). The validity of the model is verified by structural equation modeling (SEM), using the questionnaire data of university students at two universities (the university of shiga prefecture, hiroshima shudo university). The proposed model demonstrates that lecture of environment at the university enhance the pro-environmental behavior of university students indirectly. Furthermore, multiple group analysis in the structural equation modeling showed that environment measure by an environment club of the university of shiga prefecture has given a strong influence on pro-environmental behavior of students compared with environment measure by an environment club of hiroshima shudo university. 